Original Article

\title{
Rumi from the Viewpoint of Spiritual Psychology and Counseling
}

\author{
Çınar Kaya ${ }^{1}$ \\ Marmara University
}

\begin{abstract}
Rumi was a renowned Sufi, spiritual teacher, and poet who has attracted both scholarly and non-scholarly attention all over the world. This paper aims to present Rumis life and his works and contributions in the fields of thought and spirituality within themes of potential importance for both general and spiritually oriented counseling by providing some biographical details to further the understanding of his personal development as well as his approaches and contributions regarding human nature, Sufism, asceticism, love, "nothingness" within unity, and death. A biographical analysis of Rumi's own psychological transformation by Arasteh has also been presented. This paper also discusses the possibility of benefitting from Rumi texts as a resource for both spiritually oriented counseling and counseling in general, especially in the form of bibliotherapy, and attempts to outline the prospects and challenges of benefitting from Rumi and Sufi resources in general for psychotherapy and counseling.
\end{abstract}

Keywords

Rumi $\bullet$ Masnavi $\bullet$ Spirituality $\bullet$ Counseling $\bullet$ Psychotherapy

Manevi Psikoloji ve Danışma Perspektifinden Mevlana

Öz

Bu çalışmada Mevlana'nın hayatı, eserleri ve düşünce ve maneviyat alanlarındaki katkıları, gerek genel anlamda psikolojik danışmanlık; gerekse manevi yönelimli psikolojik danışmanlık süreçleri açısından dikkate değer bulunabilecek temalar altında sunulmaya çalışılmaktadır. Yaşam öyküsü Mevlana'nın kişisel bağlamının anlaşılmasına katkı sağlayacak şekilde aktarılmaya çalışılmıştır. Mevlana’nın insan doğasına bakışı, tasavvuf anlayışı, aşk, birlik içinde yok olma, zühd ve ölüm kavramına ilişkin yaklaşımları sunulmaktadır. Ayrıca Mevlana'nın kendi psikolojik dönüşümüne ilişkin Arasteh tarafından yapılmış olan bir biyografik çözümlemeye yer verilmiştir. Mevlana metinlerinin manevi danışmanlık ve genel anlamda danışma ve psikoterapi süreçlerinde bir kaynak olarak ele alınmasının imkânı tartışılmaktadır.

Anahtar Kelimeler

Mevlana • Mesnevi • Maneviyat • Psikolojik danışma • Psikoterapi

1 Correspondence to: Çınar Kaya, Educational Sciences Department, Institute of Educational Sciences, Marmara University, Istanbul 34722 Turkey. Email: cinar.kaya@marmara.edu.tr

Citation: Kaya, Ç. (2016). Rumi from the viewpoint of spiritual psychology and counseling. Spiritual Psychology and Counseling, 1, 9-25. http://dx.doi.org/10.12738/spc.2016.1.0001 
Mawlana Jalal al-Din Muhammad Rumi, usually referred to as just Rumi or Mawlana (with different spellings), was a renowned Sufi, spiritual teacher, poet, and Islamic theologian. Rumi's teachings and works have gained international reputation and acceptance as part of the world's intellectual heritage. UNESCO's declaration of the year 2007 as the "Year of Rumi" confirms this prominence and acceptance. This paper claims that Rumi's teachings and works are relevant as resources for spiritually oriented psychotherapy and psychotherapy in general, and delineates the possibilities of benefitting from Rumi in the context of counseling and psychotherapy. A basic introduction to his life and teachings has also been given with the intent of contextualizing suggestions for spiritually oriented psychotherapy and counseling.

\section{Life}

It may be necessary to review the relevancy of a thinker or spiritual teacher's life story and historical context in order to form an understanding of their teachings. Rumi's biography can also reflect stages of his spiritual development. Rumi was born as the child of an ulama (Islamic scholar) family settled in Balkh, situated in today's Afghanistan, at the onset of the $13^{\text {th }}$ century (Gölpınarl1, 2012). His father, Bahaeddin Veled, a competent Islamic scholar with the title "Sultan of Scholars," decided to leave Balkh with his family because of political pressure and the approaching Mongol invasion. This migration eventually brought them to Konya, an Anatolian city, after teaching courses along the way in different madrassas (Islamic learning centers) in various cities around Mesopotamia and Anatolia over a period of ten years. Rumi's father died two years after arriving in Konya (Gölpınarl1, 2012; Öngören, 2004). Rumi had met important Sufis and Islamic scholars of the time, and even had the opportunity to meet Attar in this period (de VitrayMeyerovitch, 2012). He received education from his father on Sufism and Islamic sciences such as theology and figh; with the death of his father, Rumi was recognized as his father's successor by his disciples and politicians (de Vitray-Meyerovitch, 2012; Gölpınarlı, 2012).

Burhanuddin Tirmidhi, a student of his father, provided Rumi with guidance towards spiritual development for nine years after his father's death. He also encouraged Rumi to visit Damascus and Aleppo to receive education from the scholars and Sufis that had settled there (Gölpınarl1, 2012). Three to four years after Burhaneddin Tirmidhi's death, a Sufi dervish by the name of Muhammed Shamsuddin of Tabriz (Shams) came to Konya in 1244 (Can, 2011; Gölpınarl1, 2012). Shams, had a very profound influence on Rumi's development. This mysterious Sufi had wandered from town to town looking for a real murshid (spiritual master); he had met with many Sufis including Ibn Arabi and had not connected with any of them, finding none of them suitable until he met Rumi (Gölpınarl1, 2012). Shams rejected the rules established by the Sufi orders of that time, such as the special dress code to reflect membership. He asked peculiar questions of Rumi when they met, and in this way they became acquainted. 
Rumi entered a different developmental direction, prioritizing experience and "love," and started novel practices such as Sema (whirling dhikr), which did not comply with the established order, mostly due to the influence of his interactions with Shams (de Vitray-Meyerovitch, 2012; Gölpinarl1, 2012). With the arrival of Shams, Rumi interrupted his regular preaching and sermons, investing less time with his disciples. He started to become "hemdem" (a term of the Mawlavi Order signifying close companionship) with Shams, entering a mutual and interactional spiritual development. This connection between Rumi and Shams was unlike the traditional Sufi sheikh-disciple relationship which is characterized by a vertical hierarchy (Can, 2011). Shams drew anger and pressure from the other disciples as the reason for Rumi neglecting them. Due to this tension, Shams left Konya after sixteen months, a relatively short time span. Rumi invited Shams to return, but he left again after a short while to unknown whereabouts. It was rumored that Rumi's elder son, Ala'ud-Din, played a role in the disappearance of Shams (Gölpınarl1, 2012).

After Shams's disappearance, Rumi began to recite poems of love, becoming an almost entirely different person (Can, 2011). His interactions with Shams had greatly influenced his teachings and poetry; he even named his divan "Divan-i Shams-i Tabrizi." Awhile after Shams's departure, Rumi lost all hope for his return; he became hemdem with Salahuddin Zarkub, a Sufi with no madrassa education, and entered a state of tranquility. After Salahuddin Zarkub's death, a joyous musical ceremony was held, as requested in his last will and testament. After this, he became hemdem with his disciple, Husamuddin Chelebi, and continued to regularly preach and lecture. The most important influence of Husamuddin Chelebi on Rumi was his inspiration to write the Masnavi (de Vitray-Meyerovitch, 2012). He requested Rumi write a poetic book describing the Sufi path which could be used to teach the principles and rules of Sufism. Until that time, books from other Sufis such as Attar had been deferred to in this respect (de Vitray-Meyerovitch, 2012).

Rumi showed his first eighteen couplets in the Masnavi poetic form to Chelebi and said he would continue if Chelebi found them to be relevant. In this way, Masnavi had begun to be written. This particular detail in Rumi's biography suggests that the Masnavi was written primarily as an educational and transformative text. Rumi would recite the couplets and Chelebi would write; this process continued for a short time until Rumi’s death (Gölpınarl1, 2012).

In the period before his death, Rumi had become increasingly withdrawn, directed towards his inner world because of the influence of saddening events such as the departure of Shams, his son's role in this disappearance, and Salahuddin Zarkub's death. Spending his last days in riyaz (abstinence) and worship, he died on December 17, 1273, attaining his "True Beloved;" this has been celebrated annually ever since 
(Can, 2011; Gölpınarl1, 2012). Jews and Christians along with the Muslim population of the city also attended his crowded funeral ceremony which was accompanied by music (Gölpınarlı, 2012).

\section{Works}

Rumi, aside from being a Sufi and scholar, was quite an efficient poet and writer in terms of the quality and quantity of his works (Schimmel, 2001, p. 164). Indian, Persian, and Divan literary influences can be observed in Rumi's works (Gölpınarl1, 2012). The Masnavi, consisting of around 50 thousand lines written over six volumes, is accepted as Rumi's basic and greatest work. It took its name from the system of verse that was used. Stories, parables, Qur'anic verses, and Hadiths (sayings of Prophet Muhammad $_{\text {pbuh }}$ ) are often included in these expressions. The Masnavi was addressed to people unfamiliar with Islamic sciences, transferring messages related to Sufism in a gentle and fun way through stories and metaphors. It includes practical instructions and is not a Qur'anic commentary in the classical sense (Lewis, 2008, p. 444). Karakoç (1996) regards the Masnavi as a fundamentally educational book with a "metaphysical plan and content," (p. 73). According to him, Rumi has "committed the Qur'an verse by verse," integrated with it, and "expressed it by solidifying its realities in the mirror of his mind and imagination," (p. 72). Karakoç, himself a poet, believes Rumi wrote his Masnavi with a preference for indirect speech so that people from all levels could benefit, aiming to "help believers become equipped with Qur'anic morality," (p. 73).

Divan-i Kebir, or the Divan-i Shams-i Tabrizi, is another great poetic work of Rumi. Fihi Ma Fih (Discourses) was formed from a series of discourses and written in prose. It is regarded as a source not just for understanding the thoughts of Rumi; but also for understanding Islamic mysticism (Sufism). The Letters is a work consisting of letters that Rumi had written to many different people. It is regarded as an important source both for understanding the surrounding historical period as well as his own personal life. Mecalis-i Seb'a (Seven Sermons) is a compilation of seven sermons given by Rumi (Gölpınarl1, 2012). Rumi was said to have written a small treatise on dreams, but this has not survived to the present day (de Vitray-Meyerovitch, 2012).

\section{Challenges with Reading Rumi}

Schimmel, who has studied Rumi extensively and been adopted as an important expert in this field (Subaş1, 2007), indicated that we do not have a unique or holistic intellectual portrait of him (2003, p. 149). According to Schimmel, the example of the Masnavi includes almost all of Sufi theories that were known in the thirteenth century. Nonetheless, it is impossible to extract a clear Sufi system of thought from the stories and narrations. Each commentator who examines the Masnavi may find as many 
themes as they wish, from personal mysticism, the unity of existence, and the glamour of love, to understanding the followers of Sunnah, (Ahl al Sunnah; Schimmel, 2001). Rumi's views on the Creator and creation were also evidently inspired by the Qur'an (Schimmel, 2001, p. 168). However, the symbolism used to depict the activities of God, ideas, and long supplications cannot be described as dogmatic opinions; a theosophical system cannot be extracted from these. Sometimes it can even be difficult to establish logical relationships. The ultimate aim was to teach the "unique attributes of God that cannot be understood through reason," (p. 166). This makes it difficult to perceive the actual thoughts of Rumi in the general process of reading.

Alongside these difficulties may be positive aspects to the non-systematic nature of Rumi's works. Texts which are portrayed as non-dogmatic may be appealing to readers of various systems of thought. Perhaps this may also partly explain why Rumi is recognized and read all over the world. Lewis (2008) stated that Rumi's scholarly competence was sufficient to author systematic works, yet he deliberately chose this particular way of expressing himself. The reason behind this preference was to improve the fluency of expression and direct the reader to think and enter into the experience by acquiring knowledge (p. 440). In this respect, Rumi's texts, particularly the Masnavi, can be considered as resources that aim to aid and guide spiritual development primarily based on experience apart from scholarly concerns. Therefore, rather than trying to map Rumi's concepts of human nature and metaphysics in this study, a focus on the love and spiritual development that may be of significance for both spiritually oriented counseling and counseling in general has been targeted.

From a psychotherapeutic perspective on Rumi, readings that stay loyal to original meanings relevant within their own context should be taken seriously as an ethical responsibility, especially when working on poetic and symbolic expressions such as those in the Masnavi and Divan. Interpretation of such texts may be challenging by their very nature, and misinterpretations can occur in some instances. To overcome this risk, people working on Rumi texts and spiritual texts in general should regard the need to respect and value the underlying accumulation of spiritual traditions, and develop competency at least as a good reader by acquiring a basic background of these traditions. Also, commentaries and annotations made on Rumi texts and other Sufi classics could be important resources for contributing to the development of psychotherapy practitioners by helping them acquire accurate understanding (Atalay, 2008).

\section{Approach to Sufism}

Sufism can be defined as the mystical or inward path of Islam (Sayar, 2014). Using the metaphor of a circle, the outer, practical dimension of Islam (Sharia and its prohibitions and rules) is likened to the perimeter of the circle and the inner truth 
becomes the center of the circle. The "radius" that leads to the center is "Tariqat" or Sufism. Sufism can be described as the spiritual way, heading not only to the implementation of external worship and belief but also to the inner satisfaction and precise knowledge that is integrated with experience (Sayar, 2014, p. 55).

Nasr (2008) described Rumi as a "peak" personage of Islam and the Sufi tradition in particular who had been firmly committed to these traditions. He argued that a large number of couplets in Rumi's Masnavi and Divan were in fact direct poetic translations of Qur'anic verses into Persian, basing these claims on an unpublished study (2008). Nasr also regards Rumi as a guide for humanity's intellectual common heritage and "Philosophia Perennis," (primordial eternal wisdom) in accordance with the moment since it is not time dependent.

Rumi was not a member of any formal Sufi order. His relationship with Shams was different from typical sheikh-disciple relationships. In fact, in one sense Shams was his "conversation Sheikh", while in another Rumi was the "Murshid," or teacher (Can, 2011, p. 319). They had a horizontal relationship, rather than a vertical one. "They transcended positions such as sheikhdom, discipleship, and successorship to become mirrors for one another," (Can, 2011, p. 57). Chittick (2003) argued that Ibn Arabi and Rumi represented two different faces of Sufism. Both were at the climax of their style and both had since left deep impacts on Sufism. Although they had different approaches on some issues, they had many aspects in common, especially the concept of love. According to Chittick, Ibn Arabi was the greatest Sufi theoretician and Rumi was the greatest spiritual poet (p. 144). Demirli also emphasized that Ibn Arabi and Rumi's views complemented each other within the accumulation of Sufism from their time. In this sense there were important parallelisms with Rumi's teachings in the form of poems and stories to Ibn Arabi's views (2013).

\section{Existence and Humanity According to Rumi}

According to Rumi, manifestations of God (reflections of being) are constantly renewed. We constantly see manifestations in numerous ways. A work of God does not resemble other works. God has different manifestations among human beings through rejoicing, crying, fearing, and hoping; God's works, activities, and manifestations on artifacts are infinitely different (Schimmel, 2003, p. 69). In the words of the Qur'an (2:30), humanity is God's "successive authority on Earth." Rumi also emphasized the distinguished role of humanity in the universe. He addressed humanity as "God's Book," "a mirror to the beauty of the Lord" with a comprehensive nature (Rumi, 2001, p. 45). According to Rumi, human beings are mirrors that can detect divine attributes and names and can reflect them into one's life (Küçük, 2007a).

As stated in the section "Challenges with Reading Rumi," Rumi's works do not contain systematic or theoretical classifications and definitions for many issues. Rumi 
did not attempt to identify or classify the elements that constitute human nature, such as the mind, nafs (Uludağ, 2006), spirit (or ruh; Yavuz, 2008), heart (or gönül; Durmuş, 2001; Kurnaz, 1996); instead, he referred to concepts used by Avicenna and Sufis as described in the Qur'an and Sunnah (Schimmel, 1980). Rumi described reason as a blessing that elevates humans, yet he found itself to be insufficient for reaching God (Yak1t, 1996). Although some studies have searched for the definition of these faculties of human existence in Rumi's works (see Arabac1, 2009; Tan, 2012), further analysis of these concepts is beyond the scope of this study.

\section{The Metaphor of the Reed Flute}

In the first verses of the Masnavi, the reed flute is used as a metaphor for "İnsan-1 Kâmil" (human perfection) as described within the Sufi tradition (Rumi, 1988/1274). In a commentary on the Masnavi, Konuk (2010) stated that even the number of holes on the reed flute point to the human body: a piece of reed is cut from the reed field and hollowed, the actions of the craftsman similar to the Insan-1 Kamil; the one who does not undergo this process resembles the Imperfect Man (İnsan-1 Nak1s). Moreover, just as the reed flute is taken from the field, humans are in pain as a result of separation from heaven and the realm of spirits. Being hollowed is important for providing the sound of the Owner untouched. The Imperfect Man does not convey the sound of the owner since they have not been hollowed. However, if one passes through the hands of a competent craftsman, is hollowed, and undergoes the necessary procedures, they may also bring forth the Sound (Konuk, 2010). The reed flute metaphor reflects the story of humanity in a surprising way. According to Rumi, the burning problem of humanity is separation from the source of our existence and true potential (Lewis, 2010, p. 444).

\section{Love}

Konuk (2010) in his commentary on the tenth couplet of the Masnavi, stated that the reason for the creation of the universe is God's love, and this love focused is called "Ishq" (Aşk in Turkish, and henceforth in this paper translated as Love) and thus represents the affection and love that surrounds all beings. In this respect, the needs that humans search for can be regarded as "beloved ones." The great Sufi theorist, Ibn Arabi, argued that Love is the fundamental force in the creation of the universe, and since there is not a true being other than God, the Lover and the Beloved is in fact Himself, using theoretical explanations with references to Hadiths (as cited in Chittick, 2003). Rumi also reflected this theme in his poems, yet did not address this issue theoretically. There were also parallel discourses on the notion of "God being the true Beloved" between these two Sufis.

Rumi taught that the hope, desire, and passion that people experience for their families, friends, the sky, the things in the earth, gardens, palaces, knowledge, 
businesses, and things like food and beverages are in fact longing for God; all these things are "curtains," and when they pass from the world, they will realize and directly experience this fact (Rumi, 2001, p. 21). There is consensus between Ibn Arabi and Rumi on the idea that Love cannot be described but can be experienced (Chittick, 2003). While Ibn Arabi defended the idea that true love may only be towards God theoretically, Rumi gave priority to fostering spiritual development and conveying to the reader the experience of love through his poetry (Chittick, 2003).

According to Rumi, when one recognizes the signs of creation by observing and thinking about creation, one sees creation as an expression of divine power and reaches God's Love, who created this world and universe so perfectly (Schimmel, 2001). In a couplet from his Divan, he likens fruit to "the coming of Mary after flowers, which have not been touched yet are pregnant." In another couplet, he likens a pretty bird to a preacher singing praises to God (Divan, as cited in Can, 2000). Rumi, similar to ones who have chosen the path of divine Love, thought that worldly love was just a preparation for divine Love. It was like giving toys to children akin to the things they will use in adulthood so as to accustom them to their roles as adults. Human love prepares the heart for surrendering to God's will. The happiness of earthly love is temporary and true Love should be directed to the Undying One (Schimmel, 1980).

\section{Nothingness in Unity}

Chittick argued that although Rumi's text does not describe theory in detail, Rumi and Ibn Arabi viewed the ability to see Truth as the prerequisite of Love (2003). People who reach proper information about their existence can experience Love. Rumi insistently advised readers to pursue suffering and to understand one's imperfections and distance from desired qualities such as wholeness, balance, moderation, wisdom, and compassion, to understand the existential poverty of the human being. Ibn Arabi also defined poverty and dependence as the most basic concepts of Sufism (Chittick, 2003).

Rumi described this poverty based on the metaphysical reality that results as a necessity of the fact that there is no real existence other than God (Rumi, 1988/1273, p. 105). He utters in a quartet "I am nothing! I am nothing! I am nothing!" (Rubais, collected by Firuzanfer \#no: 1304, as cited in Can, 2011). The Sufi notion of "nothingness" and "being a pure mirror of God" is depicted in the Masnavi in the form of a story of Chinese and Greek Painters (Rumi, 1988/1273). In the story a king makes a competition of art between two groups of Chinese and Greek artists. The Chinese artists complete an adorable painting on one side of a corridor; but the Greeks only polish the walls to the consistency of a mirror. When the curtain separating the two halves of the corridor is removed, the painting of the Chinese artists is reflected on the wall. He likens Sufis to the Greek artists in this parable: the ones who "polish their hearts are liberated from colors and smell, seeing beauty effortlessly in every breath." 


\section{Zuhd}

Zuhd is the term for Sufi asceticism in the sense that a human as God's "servant" abandons everything other than God (Ceyhan, 2014). In the process of spiritual development as taught and applied by Rumi, zuhd is one of the most important phenomena together with Love. In the Mawlawi order, which was formed based on the teachings of Rumi, zuhd is characterized as a difficult phase of spiritual development characterized with riyaz (abstinence) and struggle with the nafs (here, the evil-commanding inner faculty). Yet the heart of the spiritual salik (seeker) has not yet awakened to Love and irfan (wisdom). The practice of riyaz is performed by controlling nutrition, halwat (retreating from worldly affairs in solitude), various prayers and supplications, dhikr (remembrance, in the form of repetitions of God's Names, supplications, and so on); all are recommended for spiritual growth in this phase. These practices should be applied in a controlled manner with a proper guide or spiritual teacher and companions (Küçük, 2007a).

Rumi taught that riyaz and struggle, moods characterized by fear, and other negative feelings are necessary for zuhd, yet they should eventually be replaced by Love, irfan, deep knowledge, and balance. The salik should not be fixated on this stage. According to Rumi, in order to proceed healthily in spiritual development, it is necessary to follow a pir (spiritual master) who has transcended himself. He explains this necessity with an analogy to the fact that people cannot treat their own bone fractures but need a physician. A salik must choose the right teacher for themselves. Rumi likened the negative traits a salik needs to be rid of (such as arrogance and greed) to wounds and continued by stating that some of the interventions of the pir would displease the salik, yet they should endure them for the sake of spiritual development (Küçük, 2007a). In the first volume of the Masnavi, Rumi narrates a story about a man going to a tattoo maker in order to teach that development requires toil and suffering (Tattoing in Qazvin, Rumi, 1988/1273). However, he advised caution against people who pretend to be spiritual teachers who in reality are immature (Küçük, 2007b).

\section{Death}

Since the phenomenon of the afterlife is one of the basic beliefs of Islam and other theistic religions, death is seen as a reality that at the very least must be accepted; there are different beliefs on life after death. However, uniting the idea of joy and happiness with death may be unique to Rumi (Nasr, 2008). Rumi lived in peace with death (Can, 2011). Indeed, every year the anniversary of his death is celebrated; it is called Şeb-i Arus (wedding night) based on one of his sayings. He envisioned this worldly life as a kind of death in reality, and the death which scares us is in fact life itself; this was contrary to beliefs which see death as being born into another world (Can, 2000, p. 77). 


\section{Arasteh's Analysis on Rumi}

Rumi as both a passenger and guide on the road of spirituality primarily focused on his own spiritual development. Arasteh made a biographical analysis of Rumi's psychological transformation (2000). Arasteh (2000) examined his psychological and spiritual development particularly within the context of his interactions with Shams, who had played a strong role in his development. This analysis is hoped to contribute to our understanding of Rumi's teachings on spiritual development and the concept of Love. Arasteh described Rumi as a person who had overcome existential contradictions by surpassing the synthesis of Islam, Greek, and Indian cultures and reaching the level of universal existence (2000, p. 53). Rumi, growing in a traditional ulema family, realized that knowledge and formal instruction alone are not enough to change a human for the better. Therefore he questioned the relationships of thought, feelings, and behaviors, and the relationship between belief and action. He pondered on the sectarian and religious differences between people (p. 38).

Arasteh considered Shams as "rebellious" against classical Sufism. He had chosen to return to the interior to discover the true self, rather than taking an example from others; finally he encountered Rumi in whom he found the potential of his soul (2000, p. 40). Rumi has described his level of excellence as "individuality in non-individuality." A person in this state has reached a level of conscious being and is no longer just an "I" having a social and intellectual life but a whole universal human being characterized with spontaneity and meaningfulness benefitting from intuition. In this sense, Shams is an example of Insan-1 Kamil (Arasteh, 2000, p. 40). Rumi's conversations with Shams guided him to the experience of being a universal person, contrary to his traditional self as an educated Muslim scholar. Rumi reached this existential position through identification with Shams. His guidance in this manner resulted in him seeing himself as the "shadow of Shams." In order to get rid of the traditional self, he had to remove a variety of internal and external obstacles or "curtains."

His position in society, his "social self," his religious, traditional, and intellectual selves, and the language barrier constituted his internal barriers. He abandoned giving public sermons and isolated himself from public attention during the time he was meeting with Shams to overcome those obstacles. In this process he only saw Shams. He started novel applications such as whirling, chanting, and performing music in dhikr, and these led to the formation of the structured Sema Ceremony after his death. He enraged his followers with this kind of behavior and became subject to pressures to return to his old life-style. The followers directed their rage toward Shams. Rumi recognized the intellectual formalism and arrogance that had been brought by academic education, the hypocrisy of philosophy and reason, as his internal barriers. For Rumi, the human mind would help self-recognition up to a certain level, but was insufficient at grasping the entire self (p. 50). Arasteh described the identification of Rumi with 
Shams as quite a complex process. Shams's soul, with its spiritual and psychological characteristics, represented the universal spirit. Therefore, Rumi, instead of moving through the long stages, chose to identify with Shams not with just certain features but as a whole. Sema was his expression of love to this image, clearing his mind constantly for understanding the experience of unification. He was remembering the image of Shams to attain comfort and peace of mind (Arasteh, 2000).

Rumi identified with the image of Shams and revived it in himself by experiencing universal love in all his behaviors. He began to be increasingly interested in Love. He saw that true love was the activity of the central part of the soul. In his in-depth examinations on creation he realized a positive energy common to all particles and responsible for their relationships. This active energy which relates the entire universe to itself is Love. People would see into the depths of that Love only if they lifted the cover of this world of images. He was reborn by establishing a relationship with this power in the universe after identifying with Shams (Arasteh, 2000).

The Masnavi introduced the existential position of the human and the factors that hinder spiritual growth; the way to overcome the traditional self, authority, and formalism; integration with the universe; positive behavior and love; and eventually the establishment of close relations with the Source through unity (Arasteh, 2000). Rumi recommended the salik to make spiritual progress together with a guide and to face up to the difficult and painful aspects of spiritual development. In the Mawlawi sect, which had been formed in accordance with the teachings of Rumi, the salik first tries to recognize the self and the soul and to eliminate the unhealthy effects of the nafs, heading towards personal and social balance and perfection, avoidance of transgressions, patience, and the integration of the moral self. The Sema Ceremony improves social relationships and provides grounds for developing self-transcendence (Arasteh, 2000, p. 101). Those who reach Love as imagined by Rumi and are aware that they are already "nothing" would be naturally humble and away from qualities like arrogance, bigotry, and selfishness. Nothingness and Love are treasures for spiritual development in this regard (Arasteh, 2000).

\section{Rumi as a Resource for Spiritually Oriented Counseling}

Before using readings from Rumi's texts and teachings as a possible source for spiritually oriented counseling and psychotherapy, a clear understanding on the relationship between the areas of spirituality and psychological functioning is first necessary. Sperry and Mansager classified five basic approaches to this relationship by focusing primarily on the similarities and differences of these two fields and the issue of one's priority over the other (2003, as cited in Sperry \& Shafranske, 2007). According to the first approach, the spiritual and psychological dimensions of human 
experience and development are highly overlapping, and the psychological domain has priority over the spiritual domain. The second approach, which the authors deemed less acceptable, also considers the two areas as overlapping yet assigns priority to the spiritual domain. In the third approach, the spiritual and psychological dimensions are seen as discrete areas, and the psychological domain takes priority. Similarly, theoreticians and practitioners who have adopted the fourth approach also see the two areas as discrete, but they give priority to the spiritual domain. Those theoreticians assume that the areas of spiritual and psychological development may interact from time to time; development in one area can reflect onto the other but this is not always necessarily the case. In this approach, both spiritual disciplines and psychotherapeutic work is considered to be necessary.

According to the fifth approach, the spiritual and psychological dimensions of human experience and development are seen as distinct from one another. However, none has priority over or is reducible to the other. Spirituality and psychotherapy are seen as goal-oriented processes directed toward different objectives and requiring sequential stages. If the client's first priority is the elimination of symptoms or solving problems, psychotherapeutic interventions would be appropriate. If a client is interested in the search for transcendence or a transformation in orientation, spiritually oriented applications would be of benefit. With this holistic approach, a practitioner can easily switch between psychotherapeutic interventions and spiritually oriented interventions; they can work to help the client attain long-term goals, short term goals, and transcendental goals (Sperry \& Shafranske, 2007).

In spiritually oriented psychotherapy, when benefiting from Rumi texts or Sufi texts in general, the fifth approach would be relevant. Firstly, when spiritual development and psychological functioning are defined as distinct from each other and as two independent areas each having specific importance, an area of freedom may be opened for both the theory and practice of counseling. This delineation could free specialists from the need to "force" these two areas to become similar, such as defining a psychotherapeutic process in spiritual terms or vice versa. This in turn would enable the implementation of both disciplines of psychotherapy and spirituality in their authentic forms. This is particularly important considering the fact that the ethical and moral standards of the two disciplines may not always overlap. Another potential benefit of embracing the fifth approach may be the lack of having to assimilate, incorporate, or reduce one field into another.

Working towards spiritual development firstly requires motivational readiness. This readiness makes it easier for the practitioner to enact spiritual processes in the psychotherapeutic assistive process in harmony with the client's perceived willingness and "hunger" for spirituality. Otherwise the practitioner would either 
impose or neglect the spiritual dimension. Sufi traditions also place special emphasis on motivation and readiness for spiritual development. For example, in the Mawlawi tradition a salik is required to perform Sema only with an inner need and desire (Arasteh, 2000 p. 100). However, a practitioner can also devise interventions to increase this kind of motivation or "appetite" for spirituality along with other psychotherapeutic interventions. For instance, the previously mentioned story of "Tattoing in Qazvin" (Rumi, 1988/1273) can be used as a bibliotherapeutic resource for the nature of enacting spiritual growth.

There is also the possibility of benefitting from Rumi's texts and teachings in the general area of counseling and psychotherapy as well as with spiritually oriented counseling. Rumi readings can be illuminating for counselors and counselor candidates, nourishing the foundation of skills in regard to the conditions of counseling relationships, such as respect, unconditional positive regard, and rapport building. In terms of spiritually oriented interventions, Rumi's own suluk (mysticism) and teachings reflected into his works can be a model for spiritual development. In this sense, a counselor or practitioner should first invest time and energy to primarily understand the works of Rumi and engage in their own spiritual development. A client who interacts with a counselor or helper who is in an active process of spiritual development could possibly become open to spiritual growth through verbal and nonverbal processing. The Sufi notion of "nothingness," as noted earlier, connects the human being to an inexhaustible existence, and the distress caused by life's problems, expectations, and conflicts may be reduced to a symbolic level of existence. In this case, the severity of the problems that led to seeking psychological help (for example, interpersonal problems, financial problems) can be reduced to a phenomenological level and thus contribute to mental health and well-being.

\section{Bibliotherapeutic Use of Rumi Texts}

Bibliotherapy can be described as the deliberate use of books and literary works to help people recognize and resolve their problems and to increase their psychological functioning. In bibliotherapeutic applications, first a selected literary piece or story is read, either in counseling sessions or prior to the sessions as homework; then the clients are encouraged to share their thoughts and feelings in order to reach therapeutic outcomes such as awareness and insight by moving beyond their disclosure (Öner, 2007). Bibliotherapeutic applications have been shown to be effective with depression, and this effect has been found to persist past a three-year follow-up (Smith, Floyd, Jamison, \& Scogin, 1997).

Psychotherapeutic stories have great potential for serving as useful resources in the counseling process since they are easily understood, are usually stunning and memorable, and have indirect messages which may create grounds for identifying and 
emphasizing individual responsibility (Yüksel, 2011). Peseschkian (1986) identified eight basic functions of stories in the psychotherapy process: stories can be helpful for the client to see elements of their own situation (the mirror function); serve as models for possible solutions (the model function); serve as mediators in therapeutic communication and reducing resistance (the mediator function); contribute to the solution or strength repertoire of the client by providing memorable resources to keep their therapeutic gains (the repository effect); facilitate either the transmission of relevant elements from one's own tradition or culture (stories as transmitters of tradition); or elements from different cultures (stories as trans-cultural transmitters). Peseschkian, relevant to his psychoanalytical background, employed stories to facilitate regression. He also claimed that stories could also represent opposing views and models could provoke clients to elaborate on their own situation (stories as counter-concepts). In this sense, stories from Rumi's works, especially those from the Masnavi, have been utilized as bibliotherapeutic resources (Yüksel, 2011).

Peseschkian (1982) advocated that the use of stories and parables, especially Eastern stories, were very useful tools in achieving psychotherapeutic goals. In his book "Oriental Stories as Tools in Psychotherapy," he chose to use stories from Rumi alongside stories from personages such as Sadi, Hafiz, and Bah'ai texts (Peseschkian, 1986). Pesesckian did not aim to utilize these stories within the context of spiritual counseling, although he referred to the teachings of the Baha'i faith when commentating on the stories. He quoted Rumi's story "Darkroom and the Elephant" (Rumi, 1988/1273) as an illustration of the existence of different possible perspectives, utilizing this story to broaden the client's experiences by investing attention in the possible different aspects of a situation, person, or object (1986). Human beings have different interests, abilities, and expectations and other people may not be aware of them. Therefore people's own experience should not be replaced by a reality which, according to him, would result in various psychological problems. In this context, Peseschkian utilized the story, attending to its general psychological implications rather than its spiritual domain. Pesesckian's work also illustrates the possibility of benefitting from Rumi texts in counseling and psychotherapy in general, inspiring their utilization in spiritually oriented psychology and counseling.

In spiritual oriented or general bibliotherapy, Rumi texts can be utilized that are relevant to the context of the situation and therapeutic goals. Practitioners can work by reading short texts, working on them in a session, assigning them as homework, or in many other creative ways depending on their background and orientation. The fact that Rumi texts may appeal to people all over the world increases their functionality within the context of both spiritually oriented psychotherapy and counseling in general. Rumi texts which teach the reality of death as a positive phenomenon may be especially relevant in groups such as clients with fatal diseases who are in the grieving process. 
One of the foremost areas where practitioners can reflect the benefit of reading Rumi for psychologically assistive processes would be in client-counselor relationships. Counselors in many settings are usually seen as experts having a predominantly unidirectional relationship with the clients and thus in a developmentally static position in comparison to the client. Understanding Rumi and his views on existence and spiritual development may help practitioners soften this relatively unidirectional and vertical relationship into a more bidirectional and horizontal one in accordance with the ethical standards of the profession. This may allow a co-developmental process to be a new dimension of the therapeutic relationship.

A holistic understanding of the historical and intellectual contexts of Rumi's personality and life story as well as his works is a necessity for spiritually oriented psychotherapy. In readings from a psychotherapeutic perspective on Rumi, staying loyal to the original meanings relevant within their own contexts should be taken seriously as an ethical responsibility, especially when working on poetic and symbolic expressions such as those in the Masnavi and Divan. Interpretations of such texts may be challenging by their very nature, and misinterpretations can occur in some instances. To overcome this risk, people working on Rumi texts and spiritual texts in general should regard respect and the value of the underlying accumulation of spiritual traditions as a necessity, and they should develop competency at least at the level of a good reader who has formed a basic background. Also, commentaries and annotations made on Rumi texts and other Sufi classics can be important resources for contributing to the development of psychotherapy practitioners by helping them acquire an accurate understanding.

\section{References}

Arabacı, F. (2009). Mevlânâ'nın insana bakışı [Mevlana's view of human being] (Master's thesis, Sakarya University, Turkey). Retrieved from https://tez.yok.gov.tr/UlusalTezMerkezi

Arasteh, A. R. (2000). Aşkta ve yaratıcllıkta yeniden doğuş [Rumi the Persian: Rebirth in creativity and love] (Trans. B. Demirkol \& İ. Özdemir). İstanbul, Turkey: Kitabiyat.

Atalay, M. (2008). Hüdâvendigâr'ı anlamak: Mevlânâ'nın mirasını anlamanın bir yöntemi [Understanding Hudavendigar: A method of understanding the legacy of Mawlana]. İstanbul Üniversitesi Illahiyat Fakültesi Dergisi, 18, 163-200.

Can, Ş. (2000). Divan-1 Kebir - seçmeler (Vol. 3) [An anthology of Divan]. İstanbul, Turkey: Ötüken Neşriyat.

Can, Ş. (2011). Mevlana: Hayatı, şahsiyeti, fikirleri [Rumi: Life, personality and ideas] (9th ed.). İstanbul, Turkey: Ötüken Neşriyat.

Ceyhan, S. (2014). Zühd [Zuhd]. In TDV Encyclopedia of Islam (Vol. 44, pp. 530-533). Ankara, Turkey: Türkiye Diyanet Vakfı Yayınları.

Chittick, W. (2003). Tasavvuf [Sufism] (Trans. T. Koç). İstanbul, Turkey: İz Yayınları.

de Vitray-Meyerovitch, E. (2012). Hz. Mevlana ve İslam tasavvufu [Rumi and Sufism] (Trans. M. Aydın). Konya, Turkey: İl Kültür ve Turizm Yayınları. 
Demirli, E. (2013). İbnü’l Arabi metafiziği [Metaphysics of Ibn Arabi]. İstanbul, Turkey: Sufi Kitap.

Durmuş, İ. (2001). Kalb [Qalb]. In TDV Encyclopedia of Islam (Vol. 24, pp. 229-232). Ankara, Turkey: Türkiye Diyanet Vakfı Yayınları.

Gölpınarlı, A. (2012). Mevlana [Mevlana]. İstanbul, Turkey: Kapı Yayınları.

Karakoç, S. (1996). Mevlana [Mevlana]. İstanbul, Turkey: Diriliş Yayınları.

Konuk, A. A. (2010). Mesnevi-i Şerif şerhi [Commentary on the glorious Masnavi] (Vol 1.). İstanbul, Turkey: Kitabevi.

Küçük, O. N. (2007a). Mevlana'da benliğin dönüşümü: Süluk [Suluk: Transformation of the self in Mevlana] (Doctoral dissertation, Ankara University, Turkey). Retrieved from https:// tez.yok.gov.tr/UlusalTezMerkezi

Küçük, O. N. (2007b). Mevlânâ'nın insana bakışı [Mevlana's view of human being]. Din ve Toplum, 212, 1-11.

Kurnaz, C. (1996). Gönül [Gönül]. In TDV Encyclopedia of Islam (Vol. 14, pp. 150-152). Ankara, Turkey: Türkiye Diyanet Vakfı Yayınları.

Lewis, F. D. (2008). Mevlana: Geçmiş ve şimdi, doğu ve batı (Trans. G. Çağalı Güven \& H. Koyukan) [Rumi - Past and Present, East and West]. İstanbul, Turkey: Kabalcı Yayınevi.

Nasr, S. H. (2008). Sufi geleneği ve Rumi [Rumi and the Sufi tradition] (Trans. H. İ. Gök). In A. Karaismailoğlu (Ed.), Mevlana araştırmaları 2 [Mawlana Studies] (pp. 211-226). Ankara, Turkey: Akçağ Yayınları.

Öner, U. (2007). Biblioterapi [Bibliotherapy]. Çankaya Üniversitesi Fen-Edebiyat Fakültesi Sanat ve Bilim Dergisi, 7, 133-150.

Öngören, R. (2004). Mevlana Celaleddin-i Rumi. In TDV Encyclopedia of Islam (Vol. 29, pp. 441-448). Ankara, Turkey: Türkiye Diyanet Vakfı Yayınları.

Peseschkian, N. (1982). Oriental stories as tools in psychotherapy: The merchant and the parrot. New York, NY: Springer Verlag.

Peseschkian, N. (1986). Psychotherapy of everyday life: Training in partnership and self-help. Berlin, Germeny: Springer-Verlag.

Rumi, M. J. (1988). Mesnevi (Vol. I-VI) (Trans. V. İzbudak \& A. Gölpınarlı) [E-reader Version]. Ankara, Turkey: MEB Yayınlar1. Retrieved from: https://www.smashwords.com/ books [Original work published 1273]

Rumi, M. J. (2001). Fihi Ma Fih (Trans. A. Gölpınarl1) [Discourses]. İstanbul, Turkey: İnkılap. [Original work publication date unknown]

Sayar, K. (2014). Sufi psikolojisi: Bilgeliğin ruhu, ruhun bilgeliği (9th ed.) [Sufi psychology: The spirit of wisdom, the wisdom of the spirit]. İstanbul, Turkey: Timaş Yayınları.

Schimmel, A. (1980). The triumphal sun: A study of the works of Jalaloddin Rumi. London, UK: East-West Publications.

Schimmel, A. (2001). İslamın mistik boyutlari (Trans. E. Kocabıyı) [Mystical dimensions of Islam]. İstanbul, Turkey: Kabalcı Yayınları.

Schimmel, A. (2003). Ben rüzgartm sen ateş: Mevlana Celaleddin Rumi (Trans. S. Özkan) [I am wind you are fire: The life and work of Rumi]. İstanbul, Turkey: Ötüken Neşriyat.

Smith, N. M., Floyd, M. R., Jamison, C., \& Scogin, F. (1997). Three-year follow-up of bibliotherapy for depression. Journal of Consulting and Clinical Psychology, 65(2), 324-327.

Sperry, L. \& Shafranske, E. P. (2007). Approaches to spiritually oriented psychotherapy: A comparative analysis. In L. Sperry \& E. P. Shafranske (Eds.), Spiritually oriented psychotherapy (pp. 333-350). Washington, DC: American Psychological Association. 
Subaşı, M. İ. (2007). Batı'daki Mevlana [Mevlana in the West]. İstanbul, Turkey: Nesil Yayınları.

Tan, Y. (2012). Mevlânâ düşüncesinde Tanrl-insan ilişkisi [God-human relationship in Mawlana's thought] (Master's thesis, Süleyman Demirel University, Turkey). Retrieved from https://tez.yok.gov.tr/UlusalTezMerkezi

Uludağ, S. (2006). Nefis [Nafs]. In TDV İslâm Ansiklopedisi (Vol. 32, pp. 526-529). Ankara, Turkey: Türkiye Diyanet Vakfı Yayınları.

Yakıt, İ. (1996). Mevlânâ'da akıl ve aklın kritiği [Mind and its critique in Mevlana]. Süleyman Demirel Üniversitesi İlahiyat Fakültesi Dergisi, 3(3), 1-20.

Yavuz, Y. Ş. (2008). Ruh [Spirit]. In TDV Encyclopedia of Islam (Vol. 35, pp. 187-192). Ankara, Turkey: Türkiye Diyanet Vakfı Yayınları.

Yüksel, A. Ş. (2011). Psikoterapötik bir teknik olarak hikaye ile tedavi: Mevlana'nın Mesnevi'si örneği [Therapy with stories as a psychotherapeutic method: Rumi's Mathnawi as an instance]. (Master's thesis, Istanbul University, Turkey). Retrieved from: https://tez. yok.gov.tr/UlusalTezMerkezi 